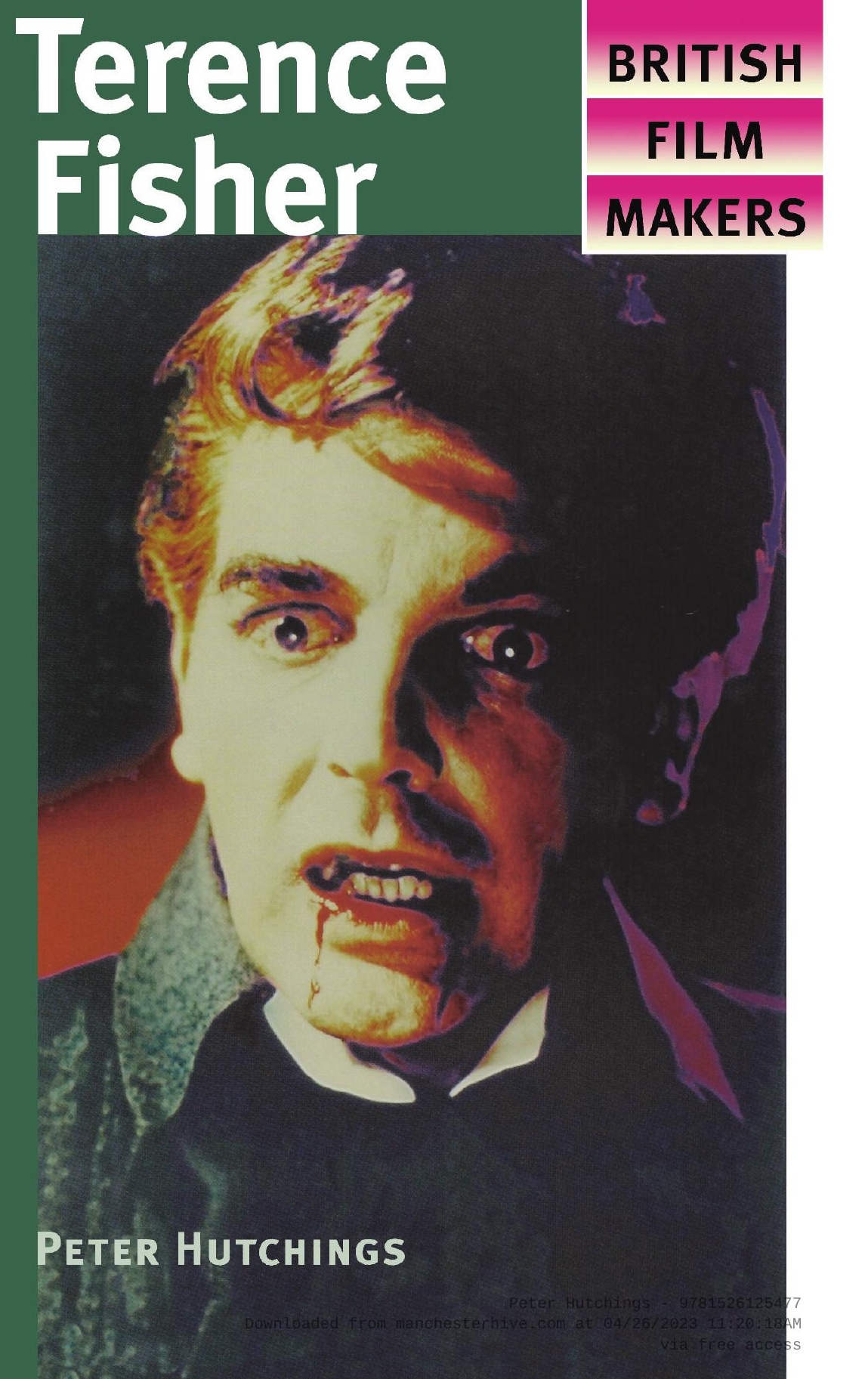




\section{Terence Fisher}


BRIAN MCFARLANe, NeIL SINYARD series editors

BRITISH

Allen Eyles, Philip French, Sue Harper, FILM

TIM PULLEINE, JEFFREY RICHARDS, TOM RYALL series advisers

MAKERS

already published

Jack Clayton NEIL SINYARD

Lance Comfort BRIAN MCFARLANE

J. Lee Thompson STEVE CHIBNALL 


\section{Terence Fisher}

BRITISH

FILM

MAKERS

Peter Hutchings

Manchester University Press

MANCHESTER 
Copyright @ Peter Hutchings 2001

The right of Peter Hutchings to be identified as the author of this work has been asserted by him in accordance with the Copyright, Designs and Patents Act 1988.

Published by Manchester University Press Altrincham Street, Manchester, M1 7JA, UK www.manchesteruniversitypress.co.uk

British Library Cataloguing-in-Publication Data is available

Library of Congress Cataloging-in-Publication Data is available

ISBN 9780719056376 paperback

First published by Manchester University Press 2001

This paperback edition first published 2013

The publisher has no responsibility for the persistence or accuracy of URLs for any external or third-party internet websites referred to in this book, and does not guarantee that any content on such websites is, or will remain, accurate or appropriate. 